\title{
Barnet som instrument: Kritik av titoistisk diskurs i Aleksandar Hemons "Islands» och Alma Lazarevskas "Blagdan krunice»
}

\author{
Fedja Wierød Borčak* \\ Institut for Engelsk, Germansk og Romansk, Københavns Universitet, Danmark
}

\begin{abstract}
The Child as an Instrument: Criticism of Titoist Discourse in Aleksandar Hemon's 'Islands' and Alma Lazarevska's 'Blagdan krunice'

Especially since the war in the 1990s, much Bosnian-Herzegovinian fiction has employed the perspective of the child in order to express criticism of dominant ideological narratives. This article views the child figure as a political device that exposes the mechanisms of certain dominant discourses and that offers new, deviating angles on well-established conceptions within these discourses. The analysis of Alexander Hemon's short story 'Islands' (2000) stresses the grotesque imagery associated with the perception of the boy narrator as a way of 'unlearning' notions of Yugoslav modernity as idyllic, even paradisiac. And in Alma Lazarevska's 2003 'Blagdan krunice' (The Feast of the Rosary) the focus is not so much on the perspective of the boy protagonist as on his function as an arena for projecting narratives of the heroic soldier on the threshold between Yugoslav and post-Yugoslav discourse.
\end{abstract}

Keywords: Bosnia and Herzegovina, Titoism, child perspective, Aleksandar Hemon, Alma Lazarevska

På 90-talet korades den fjortonåriga Zlata Filipović till Bosniens Anne Frank efter att hennes dagbok getts ut på engelska. ${ }^{1}$ Zlata's Diary beskrev Bosnienkrigets vardag ur en tonårings perspektiv och blev en bestseller i väst. I en recension av boken vädrade den amerikanska korrespondenten David Rieff (1994, s. 32), som själv följde kriget på plats, sin frustration över det faktum att "it is the war as seen through a child's eyes that is being presented as the deepest truth of the Bosnian situation». Han ifrågasatte det han såg som en tendens att låta förenklade och sentimentala redogörelser av (och om) barn överskugga komplexa analyser av kriget. Filipovićs bok stod i bjärt

${ }^{1}$ Delar av denna artikel baseras på resultat i min doktorsavhandling (Borčak, 2016).

^Kontaktinformasjon: Fedja Wierød Borčak, e-post: fwb@hum.ku.dk 
kontrast till hans och en hel journalistkårs ansträngningar att rapportera om kriget, däribland om grova krigsbrott, på ett nyanserat och ansvarsfullt sätt som matchade konfliktens komplexitet.

Mot bakgrund av Rieffs påpekande är det ironiskt att just barnperspektivet, såsom det har använts i den bosniska litteraturen, tvärtom har fungerat som ett kritiskt och nyanserande verktyg i motstånd mot dominerande ideologiska berättelser om kriget i Bosnien-Hercegovina eller om tiden under Jugoslavien. I anmärkningsvärt hög grad har barngestalten fått rollen som observatören som förfrämligar, löjliggör och bryter ned de stora berättelsernas anspråk, vare sig de har titoistiska, etnonationaliska eller balkanistiska förtecken. Tendensen är också synlig i andra medier, till exempel i fotografen Milomir Kovačevićs (2012) porträttbilder av barn poserande med vapen i krigets Sarajevo som kastar ljus på konsekvenserna av militaristiska maskulinitetsideal härrörande från Jugoslavien-tiden (ett ämne som även blir aktuellt i denna artikel). Så sent som 2017 öppnades Muzej ratnog djetinjstva (Krigsbarndomens museum) i Sarajevo, som samlar barndomsberättelser och -minnen från kriget och som uttryckligen vill verka som en kraft för försoning (Sheehan, 2018). Barnet har kommit att bli ett narrativt instrument med en politisk potential.

Den mest kända romanen som använder barnet i kritiskt syfte, Nenad Veličkovićs Konačari (Övernattarna, 1995), blev till under kriget och distribuerades i sin första levnadstid runt i enkla, häftade manusexemplar i en liten krets. Boken är ett direkt och parodiskt svar på böcker som Zlata's Diary och handlar om en tonårstjej i det belägrade Sarajevo som för att få tiden att gå bestämmer sig för att börja föra dagbok. Genom huvudpersonens naivitet, fantasi och lekfullhet lyckades boken både parodiera inhemska nationalistiska narrativ och kritisera västerländsk media för dess slarviga förenklingar av krigets karaktär (Vervaet, 2011, s. 8). Veličković fortsatte att använda barnfiguren i romanen Otac moje kćeri (Min dotters far, 2000) och den dyker också upp i böcker som Sarajevski Marlboro (1994) och Mama Leone (1999) av Miljenko Jergović. Semezdin Mehmedinović använder i viss utsträckning figuren i Sarajevo Blues (1992) och detsamma gör författare som Šejla Šehabović, Cecilija Toskić och Lejla Kalamujić. Det är också ett vanligt grepp hos bosniska migrantförfattare som skriver på andra europeiska språk än bosniska, kroatiska eller serbiska, exempelvis Saša Stanišić, Ivana Bodrožić och Aleksandar Hemon, vars ena novell analyseras nedan. I ett skandinaviskt sammanhang kan man nämna Alen Meškovićs romaner på danska, Ukulele fam (2011) och Enmandstelt (2016), där det besläktade tonåringsperspektivet gör sig gällande.

Ibland präglar författaren barnets berättelse med satiriska undertoner och gör barnfiguren till en mer eller mindre uppsökande ironiker. Veličković (2013, s. 227) talar i en artikel om barnets subversiva potential som åtminstone delvis baserat på en "hälsosam egoism och hedonism", som möjliggör en hög grad av ansvarslöshet i förhållande till samhälleliga strukturer, vilket $\mathrm{i}$ sin tur resulterar i dekonstruktionen av dessa strukturer. Denna medvetet ironiska metod är emellertid på intet sätt den enda och det finns anledning att titta närmare på texter som i större utsträckning erkänner 
barnets delaktighet $\mathrm{i}$ de diskurser som angrips. I föreliggande artikel har jag valt att fokusera på två noveller, där barnfiguren på olika sätt är fångad i de vuxnas ideologiska strukturer. Den första som analyseras är Aleksandar Hemons novell "Islands» från The Question of Bruno (2000), vars huvudperson, en nioårig pojke, introduceras för den jugoslaviska kommunismens våld på en resa till semesterön Mljet. I den andra texten, "Blagdan krunice» (Rosenkransfesten) från novellsamlingen Biljke su nešto drugo (Växter är någonting annat, 2003) av Alma Lazarevska, är fokus på en pojke vars identitet präglas av den jugoslaviska bilden av den heroiska soldaten som ett mansideal.

Mitt syfte är att visa hur barnfiguren används som ett kritiskt och politiskt instrument med avsikt att synliggöra och underminera problematiska sidor av i det här fallet främst titoistisk diskurs. Denna artikel är även ett försök att presentera en metodologisk strategi som skiljer sig från tidigare forsknings tendens att stanna vid barnets säregna perspektiv som ett kritiskt medel. Istället för att fokusera på en starkt dikotomisk relation mellan barnet och den diskurs som kritiseras föreslår jag ett fokus som spårar de diskursiva implikationerna som åtföljer barnets kontakt med den diskurs som angrips. Det räcker inte att påtala att barnet negerar eller förkastar diskursen i kraft av sitt speciella perspektiv, utan det är nödvändigt att se hur diskursen blir synlig, öppnas upp och potentiellt kan förhandlas om.

\section{Det politiska barnet}

I ett litteraturhistoriskt perspektiv har barnet varit ett öppet koncept och en projektionsyta för den vuxna författarens önskningar: »in envisioning the child, writers have constructed images and characters that serve various functions: instruction, allegory, pathos, escapism, satire, identification, demonization, or idealization» (Gavin, 2012 , s. 2). Bruket i den bosniska litteraturen knyter i huvudsak an till en tidigare jugoslavisk tradition inom litteratur och film, där barnet har varit ett medel genom vilket man har förstått historiska skeenden och samhällsförändringar, såsom andra världskriget eller upplevelsen av den kommunistiska regimens stigande illegitimitet på 80-talet. Ett känt litterärt exempel är Bora Ćosićs roman Uloga moje porodice u svetskoj revoluciji (Min familjs roll i världsrevolutionen, 1969) och på 80-talet kom filmer som Emir Kusturicas Sjećas li se Dolly Bell (Kommer du ihåg Dolly Bell, 1981) och Otac na službenom putu (Min far på affärsresa, 1985). I ett bredare europeiskt perspektiv kan man säga att barnet under 1900-talet har varit något av en nyckelgestalt i litteratur som behandlat olika diktaturers historia och samhälle (Nykvist, 2013, s. 94). Man kan därför även dra linjer mellan barnfiguren i den bosniska litteraturen och exempelvis den tyska efterkrigslitteraturen som också använder barnfiguren i liknande syften, till exempel Günter Grass antinazistiska Die Blechtrommel (Blecktrumman, 1959), Siegfried Lenz Deutschstunde (Tysktimmen, 1968) och Christa Wolfs Kindheitsmuster (Barndomsmönster, 1976), som kritiserar det östtyska kommunistiska styret. 
I likhet med dessa traditioner fungerar barnet i den postjugoslaviska bosniska kontexten som ett politiskt grepp, som vänder sig utåt, mot dominerande ideologiska diskurser som upplevs som förtryckande och som man med hjälp av barnfiguren kan skärskåda och genomskåda. Med "dominerande diskurs» avser jag här ett priviligierat socialt-ideologiskt mönster som determinerar meningsskapande genom särskilt innehåll, figurer och premisser. I de texter av Hemon och Lazarevska som jag analyserar nedan är det framför allt den jugoslaviska modernitetsdiskursen som angrips. Flera forskare har tidigare påpekat den politiska aspekten i användningen av barnet. Enligt Kazaz (2004, s. 163) är den infantila diskursen som åtföljer barnet, eller det han närmare bestämt kallar "narrationens infantilisering» (infantilizacija naracije), rotad i ett starkt etiskt engagemang hos författare som på 90-talet satte sig för att underminera stora berättelser (särskilt nationalistiska) och förfäkta betydelsen av att skildra den individuella erfarenheten av kriget. För Denić-Grabić (2010, s. 204) erbjuder det "decentrerade», marginella barnperspektivet en möjlighet att hitta svaga punkter i den dominerande diskursen, och Avdagić (2012, s. 140) understryker att den "naiva berättaren» möjliggör formuleringen av en rörlig, flytande politisk position som kringgår vanliga ideologiska fällor. Även Hansen-Kokoruš (2013, s. 24-25) ser i den barnsliga instinkten en möjlighet för en grundläggande »demaskering och dekonstruktion» av konventioner och traditioner, vilket i sin tur lägger grunden för ideologikritik. I dessa kommentarer baseras den kritiska potentialen mycket riktigt på läsarens förväntning på barnets unika (oskyldiga, naiva, instinktiva) status och (begränsade, skeva) perspektiv på världen, två grundläggande aspekter som gör det möjligt att formulera alternativa berättelser om politiska och historiska skeenden.

Föreställningen om barnets unika, ursprungliga tillstånd är resultatet av ett romantiskt tankegods, som ser barndomen som "a lost, idealized, clear-visioned, divinely pure, intuitive, in-tune-with-nature, imaginative stage of life" (Gavin, 2012, s. 8). Här är barnets ursprungliga väsen tänkt som ett botemedel mot de vuxnas förstelnade, konventionella värld där allt är föregivettaget och inget kan ändras och denna förståelse har i hög grad influerat det politiska barnets annanhet. I mera konkreta termer utgörs barnperspektivets annanhet i huvudsak av (1) barnets begränsade intellektuella och erfarenhetsmässiga ramverk och (2) dess fysiska begränsningar. Barnet saknar alltså tillgång till diskursen i två viktiga bemärkelser: det saknar både det konventionella språket och själva tillgången till samtalet. När de vuxna talar stängs barnet rent fysiskt ute och tvingas tjuvlyssna, hitta ledtrådar och dra egna slutsatser i periferin av logos. Barnfigurens kritiska potential ligger i just denna spänning och den frihet som följer med dess satellitliknande position i förhållande till vuxenvärlden:

To recognize the child's exclusion from adult language and discourse does not mean that children's voices are condemned to being disabled in literary representations. On the contrary, many texts written from a child's viewpoint are brilliantly creative, subversive, 
or compensatory precisely because children speak from a realm as yet unappropriated, or only partially appropriated, by social or cultural intentionality. (Goodenough, Heberle \& Sokoloff, 1994, s. 4)

Denna perifera position som barnet intar är besynnerlig, eftersom den på ett paradoxalt sätt på samma gång innebär en förmodad subaltern, röstlös position (barnet saknar tillgång till logos) och en frigörande kreativitet (barnet leker med logos). Barnet både besitter språk och saknar det. Man kan förklara detta med att barnfiguren nödvändigtvis är ett pseudobarn i det att dess värld formuleras och approprieras av en vuxen författare (Vice, 2005). Författaren ger barnet röst men exploaterar samtidigt barnets antagna röstlösa position i ett försök att röra sig undan konventionella koncept och föreställningar.

Barnets språklöshet innebär att det grundläggande är apolitiskt. Filosofen Jacques Rancière (2010, s. 37) hänvisar till Aristoteles distinktion mellan det politiska subjektet i besittning av logos och djuret vars ljud är "appropriate only for expressing the feelings of pleasure and displeasure». Enligt Rancières lite okonventionella förståelse av begreppet är politik först och främst en kamp om den dominerande symboliska ordningen, vilken styr vad som kan tänkas, kännas och sägas samt hur det blir formulerat och vem som tillåts formulera det. Han kallar denna ordning för partage du sensible. En litterär handling är politisk i den utsträckning den stör ordningen - $\mathrm{i}$ den utsträckning som den producerar "new subjects and objects, (...) [renders] visible what had not been, and [makes] heard as speakers those who had been perceived as mere noisy animals» (Rancière, 2009, s. 25). När forskare exempelvis framhäver den bosniska krigslitteraturens emfas på den individuella erfarenheten är denna emfas politisk därför att den gör individen synlig $i$ en ordning som annars har präglat de stora berättelsernas makroperspektiv, där agenten primärt har varit kollektivet. Det politiska består i att omarrangera existerande tecken, bilder och förbindelser som förknippas med den dominerande ordningen.

Det metodologiska imperativet som springer ur detta sätt att förstå den estetiska texten som en politisk handling är att söka efter punkter där barnfiguren används för att störa eller manipulera den attackerade dominerande diskursen. Tidigare har man i stor utsträckning stannat vid barnperspektivets subversiva karaktär i sig, som gärna förklarats med hjälp av narratologiska omständigheter, utan att de fina diskursiva processerna i barnets infiltrering av den dominerande diskursen har ägnats uppmärksamhet. Ett mera diskursivt fokus möjliggör en mer finkornig förståelse för kritiken som produceras, både rent litterärt-tekniskt och i politisk mening. Därför kommer jag nedan att fokusera mer på själva interaktionen som uppstår än på perspektivet, även om perspektivet nödvändigtvis determinerar interaktionen och därmed är en oundgänglig del av den. Jag har annorstädes använt termen "subversiv infantilisering» för att beteckna de tekniker med hjälp av vilka texten via barnfiguren anammar (tar i sin mun) en diskurs för att blotta dess problematiska sidor (Borčak, 2016). Termen är lite klumpig men har den fördelen att den understryker fokus på en dynamisk process snarare än ett statiskt perspektiv. 


\section{Det sönderfallande paradiset}

Hemons berättelse "Islands» dök första gången upp i ett nummer av tidskriften Ploughshares (1998) och två år senare som inledningsnovell i debutboken The Question of Bruno (2000). Samlingen, som blev Hemons genombrott, problematiserar frågor som historia, identitet, krig och migration och är tydligt inspirerad av författare som Conrad, Nabokov och Kiš. »Islands» återges av en vuxen berättare som minns tillbaka på barndomens och 70 -talets Jugoslavien och närmare bestämt en särskild semester som familjen firade vid den adriatiska kusten en sommar. Novellen är indelad i 33 korta episoder, vars kronologiska men lösa relation sinsemellan i hög grad påminner om ett slags minnets arkipelag där intrycken, ett efter ett, tycks bubbla upp till ytan. Strukturen och vissa språkliga detaljer avslöjar ärligt den vuxna berättarens närvaro, men perspektivet är i allmänhet den unga pojkens och det är genom hans upplevelser som semesterön Mljet avslöjas för läsaren, bit för bit.

Novellen har flera intressanta spår. Det är å ena sidan en reflektion över den drömlika erinringens uppbyggnad och å andra sidan en Bildungshistoria, vars oavslutade övergångsrit handlar om att nyansera den idealiserade bilden av det kommunistiska Jugoslavien genom att bli varse dess våldsamma sida och inte minst det Zink (2014, s. 96) kallar statens "problematischen Gründungsmythos». Inledningsvis är det tydligt att pojken reser till Mljet som jugoslav och kommunist, vilket märks i den glada omfamningen av sentimental-heroisk diskurs:

I sang communist songs the entire journey: songs about mournful mothers looking through the graves for their dead sons; songs about the revolution, steaming and steely, like a locomotive; songs about striking miners burying their dead comrades. By the time we got to the coast, I had almost lost my voice. (Hemon, 2000, s. 3)

Den naiva, okritiska inställningen som sången representerar är en upptakt till den nedbrytning av den idealiserade bilden av det kommunistiska Jugoslavien som sker på flera plan. Desillusioneringsprocessen underbyggs delvis med hjälp av pojkens farbror, Julius, som har överlevt ett sovjetiskt Gulagläger på 40-talet och som insisterar på att berätta om sina upplevelser därifrån. Mera grundläggande drivs uppmärksamheten mot våldet och människornas korruption av paradiset av barnets speciella blick, som skär ut och proportionerar världen på ett radikalt avvikande sätt. Denna premiss stakas ut i begynnelsen, när familjen just stigit av båten och läsaren får ta del av pojkens första intryck av resmålet:

We saw the thin stocking of smoke on the horizon-thread, then the ship itself, getting bigger, slightly slanted sideways, like a child's drawing. I had a round straw hat with all the seven dwarfs painted on it. It threw a short, dappled shadow over my face. I had to raise my head to look at the grown-ups. Otherwise, I would look at their gnarled knees, the spreading sweat-stains on their shirts and sagging wrinkles of fat on their thighs. One of the Germans, an old, bony man, got down on his knees and then puked over the pier edge. The vomit hit the surface and then dispersed in different directions, like 
children running away to hide from the seeker. Under the wave-throbbing ochre and maroon island of vomit, a school of aluminum fish gathered and nibbled it peevishly. (Hemon, 2000, s. 3)

Barnets blick gör sig primärt gällande genom en fysisk begränsning, eller det man skulle kunna kalla barnets "optiska perspektiv» (Spielmann, 2002, s. 223), som på ett elegant sätt etableras med hjälp av pojkens korta längd och hans hatt med de sju små dvärgarna. På grund av hans längd och den avskärmande hatten riktas pojkens fokus bort från det de vuxna normalt förbinder med ön mot andra, mycket mindre smickrande egenskaper hos den. Den dominerande "motdiskursen» som pojken spelar mot präglas i huvudsak av föreställningen om ön som en paradisliknande plats. Detta indikeras på flera ställen i texten och är omisskännlig även för läsare som inte känner till den historiska bakgrunden. Dock är kontexten inte desto mindre viktig för paradistropens koppling till den kommunistiska moderniteten. Beganović (2012, s. 152-153) påpekar att Hemons Mljet representerar en arkadisk plats och att ön litteraturhistoriskt ofta har förbundits med idyll - till exempel levde barockpoeten och munken Ignjat Đorđić här, på en holme i en sjö på ön, "the space of idyllic seclusion par excellence». I övrigt var Mljet en del av den omfattande jugoslaviska turismboomen från 60-talet och framåt. Resmål längs den adriatiska kusten framställdes ofta som paradisiska platser; annonser beskrev kusten som "a fragment from the Garden of Eden, where islands and ancient cities were linked together by a golden thread of history» (Duda, 2010, s. 298).

Vad som är viktigt i relation till novellens desillusioneringstema är att turismen ingick i diskursen om den vällyckade jugoslaviska moderniteten. Samtidigt som den var en betydande inkomstkälla för staten och bidrog till en stark ekonomi var den ökade möjligheten för den inhemska medelklassen att semestra vid kusten en symbol för nationens socioekonomiska välmående (Duda, 2010, s. 303). Kusten var också en symbol utåt och den internationella turismen var betydande (spår av det $\mathrm{i}$ Hemons berättelse kan man se i de få tyskar som nämns). Mljet är i detta avseende inte bara ett idylltopos i novellen, ön ska också förstås som en symbol för den kommunistiska nationens succé och som en del av titoismens modernitetsdiskurs.

Den underliggande diskursen om det kommunistiska paradiset avbryts som sagt gång på gång av pojkens fokus på mindre smickrande delar av ön. För det första tilllåter det optiska perspektivet, som man kan se i den ovan citerade passagen, en värld som går från knäna nedåt och som vid upprepade tillfällen tangerar det motbjudande: "I would look at their gnarled knees, the spreading sweat-stains on their shirts and sagging wrinkles of fat on their thighs» (Hemon, 2000, s. 3). Så snart pojken har satt sin fot på ön ser han en tysk turist spy och hans kringflytande uppkast nafsas fort upp av småfisk. Beskrivningen av farbror Julius (och de vuxna i allmänhet) styrs av samma detaljerade uppmärksamhet mot det groteska: "he grinned at me, showing his pink gums with cinnabar scars. He reeked of pine cologne, but a whiff redolent of rot and decay escaped his insides and penetrated the cologne cloud" (Hemon, 2000, 
s. 5). Och Julius fru, Lyudmila, har i sin tur "a loaf of bread with a small tubby potato in the middle, arms akimbo, her calves full of bruises and blood vessels on the verge of bursting, ankles swollen" (Hemon, 2000, s. 6). Öns vackra natur störs oavbrutet av gestalternas groteska kroppar.

Hemon är emellertid inte entydig när det gäller betydelsen av pojkens hatt för barnperspektivet. Å ena sidan representerar hatten som optisk begränsning ett avvikande - eller till och med subversivt - barnperspektiv, å andra sidan kan den förstås som ett hinder i den utvecklingsresa som pojken genomgår. I själva verket mister pojken hatten $i$ vinden rätt tidigt $i$ historien och Hemon gör påfallande mycket ut av dess försvinnande: "I watched the hat teetering away, my hair pressed against my skull, like a helmet, and I understood that I would never, ever see it again. I wished to go back in time and hold on to my hat before the surreptitious whirlwind would hit me in the face again» (Hemon, 2000, s. 4). Det antyds att det är en del av barndomen som flyter iväg och som aldrig kommer igen; förmodligen representerar hatten den oskuld och naivitet som i slutändan måste förloras för att pojken ska förstå de ohyggligheter han blir presenterad för. Oavsett vad försvinner på intet sätt barnperspektivets groteska prägel, vilket man inte minst ser i naturbeskrivningarna, där Mljet framställs i sin mest våldsamma form, exempelvis när pojken ser en tysk man bussa sin schäferhund på en mungo som slits i stycken: "There was a hole in its chest - the dog seemed to have bitten off a part of it - and I saw the heart, like a tiny tomato, pulsating, as if hiccuping, slower and slower, with slightly longer moments between the throbs, and it simply stopped» (Hemon, 2000, s. 14-15).

Det genomgående groteska inslaget fyller en viktig funktion i novellens barnperspektiv, först och främst därför att det möjliggör en distansering till de vuxnas vedertagna föreställningar om vad Mljet är och vad det representerar. Traditionellt brukar det groteska förknippas med effekten av ett slags kreativ instabilitet och osäkerhet, eftersom det bidrar till disproportioneringen av vedertagna former. Edwards och Graulund beskriver således det groteskas grundläggande funktion som "the ungrasping of forms» och fortsätter:

This process of systematic unattachment, in turn, acknowledges the possibilities of an open structure in which there can be no certainty, no exclusive or permanent state of something which does not already contain within it something else: there is no beauty without ugliness, no comedy without tragedy, no black without white. (Edwards \& Graulund, 2013, s. 3)

Likaledes sätter barnets groteska perception igång ett förfrämligande och därmed en omförhandling av Mljets paradisiska konnotationer genom att hitta det fula i det vackra, det helvetiska i det himmelska. Om man har i åtanke det paradisiska elementets inkludering i den kommunistiska modernitetsberättelsen, så utgör perceptionens öppenhet ett slags avlärande av den dominerande titoistiska diskursen, och därmed får pojkens perspektiv ett politiskt anslag i den rancìrska mening som 
jag skisserade ovan. Det öppnas upp ett rum för en omprioritering av vilka koncept tillåts konstituera det kommunistiska projektet. Man skulle kunna precisera denna process med hjälp av Tygstrups och Holms tankar om litteraturens kapacitet att intervenera i dominerande diskurser. I likhet med (och i direkt anknytning till) Rancière uppfattar Tygstrup och Holm (2012, s. 204) den litterära texten som deltagande $i$ "a struggle between ways of forging images of what reality looks like and what it ought to look like». Ett sätt interventionen sker på är skapandet (creation) av nya bilder, begrepp och synvinklar som typiskt inte innefattas i den gällande dominerande diskursen. Detta handlar inte primärt om att finna nya objekt i världen utan om att omkonfigurera vår perception och förståelse av fenomen som redan existerar, men som vi är föga eller inte alls medvetna om. "Islands» hämtar in aspekter från det Laclau och Mouffe (2001, s. 98) kallar "the field of discursivity", det vill säga det fält som innefattar aspekter som direkt exkluderas från diskursen. Här rör det sig i första hand om att låta (det annars exkluderade) våldet och skräcken samexistera med det idylliska. Nedan blir kopplingen till den historisk-politiska dimensionen tydligare, eftersom synliggörandet relateras till idén att moderniteten grundläggande vilar på förtryck.

Det historiska våldet presenteras först och främst av farbror Julius i hans berättelser om sin tid i ett Gulagläger i Arkhangelsk, men ett kommande våld förebådas också genom en serie av omen som indikerar en ny katastrof. Båda dessa aspekter är indirekta och indikeras med hjälp av antydningar. I berättelserna från Arkhangelsk-lägret på 40-talet hinner verkligheten på sätt och vis ifatt varje tänkbar grotesk fantasi. Julius berättar om sitt arbete med att gräva stora gravar och proppa in så många lik som möjligt i dem. "Fifty per grave was the prescribed amount. Sometimes he had to stamp on the top of the graveload to get more space and meet the plan» (Hemon, 2000, s. 10). Förutom om de eländiga förhållanden med trånghet och hunger berättar Julius att det en dag plötsligt kom massvis av barn till lägret efter att Stalin hade formulerat ett dekret om att barn som inte gick i skola skulle få minst sex månader i arbetsläger som straff. Det var ungdomar lite äldre än novellens unga huvudperson, som spänt sitter och lyssnar. Det är särskilt en pojke farbrodern minns, Vanyka, som överlevde längre än de flesta, bland annat genom att mörda. Vanyka sätts så småningom på en ö, dit "the worst of the worst» kom och där fångarna lämnas åt sig själva med nästan ingenting att äta förutom varandra. "The nearest guard was on the shore fifty kilometers away. They let the inmates rob and kill each other like mad dogs» (Hemon, 2000, s. 11).

Det är intressant att Hemon inte vid något tillfälle berör den jugoslaviska regimens våld direkt. Istället använder han ett antal associationer som utan tvekan styr läsaren att betrakta det sovjetiska våldet som någonting även jugoslaviskt, åtminstone delvis. Den antitetiska kopplingen mellan den helvetiska Gulag-ön och det himmelska Mljet är svår att undgå, liksom identifikationen med Vanyka som uppstår hos pojken. Vanyka är en sorts inverterad spegling av pojken. Och nästa länk i associationskedjan ligger nära till hands: Jugoslaviens ökända fångläger på ön Goli otok, där 
den kommunistiska regimen massfängslade dissidenter under svåra förhållanden (se Gorup, 2007).

Metoden att använda sovjetiska analogier för att tala om jugoslaviskt våld tycks i förstone omständlig. Emellertid är det meningsfullt inom ramen för pojkens påbörjade medvetandegörande. Hemon tycks mena att pojken, som alltjämt är starkt inlemmad i kommunistisk diskurs, ännu inte äger ord - eller är redo mentalt - för att möta detta våld direkt. Den analogiska tillgången gör sig även gällande när Julius påtalar en allegorisk relation mellan den marxistiska idén om dialektal materialism och de otaliga mungor som strövar omkring på Mljet. Han berättar att det en gång $i$ tiden fanns oändligt många ormar på ön - ormbett var lika vanliga som myggbett och för att råda bot på problemet importerade man mungor från Afrika som åt upp ormarna i stora mängder. Men så började kycklingar och katter försvinna och det gick rykten om rabida och monstruösa mungor, som var resultatet av "paradisiacal inbreeding» och som tog kål på varandra (Hemon, 2000, s. 6). "'Now they were trying to figure out how to get rid of mongooses. So that's how it is', he said, 'it's all one pest after another, like revolutions. Life is nothing if not a succession of evils,' he said, and then stopped and took a pebble out of his left sandal» (Hemon, 2000, s. 6). Orden - och novellen som helhet, inser man - ekar Danilo Kiš novellsamling Grobnica za Borisa Davidovića (En grav för Boris Davidović, 1976), vars centrala idé är att visa hur de stora revolutionerna (bland annat den ryska) ödelägger och slukar den individuella människan.

Om Julius intention är att väcka pojken ur sin idealistisk-kommunistiska slummer, så lyckas han med det. Avsnittet efter historien om Vanya inleds med: "I woke up and didn't know where I was or who I was» (Hemon, 2000, s. 7). Pojken genomgår en långsam utveckling alltmedan hans speciella barnperspektivs uppmärksamhet riktas mot aspekter som underminerar det kommunistiska projektet. Vid upprepade tillfällen refererar texten till Jugoslaviens ledare Tito på ett sätt som signalerar ihålighet och övergivenhet. Det första pojken märker i receptionen till semesterlägenheten är "the sonorous chill of a large stone-walled hall. There was a reception desk, but nobody behind it, and a smiling Tito picture over the numbered cubbyhole shelf» (Hemon, 2000, s. 17). Den närmast gotiska stämningen återfinns i en tidigare passage:

There was an aerial picture of a winding island (Mljet, it said in the lower right corner) and a picture of Comrade Tito, smiling, black-and-white, on the opposite wall. Below the window, the floor was dotted with mosquitoes - with a large green-glittering fly or a bee here and there - still stricken by the surprise. When I moved towards them, the wisp caused by my motion made them ripple away from me, as if retreating, wary of another surprise. (Hemon, 2000, s. 7)

Diskrepansen mellan den leende Tito, symbolen för jugoslavisk enighet, och den ödesmättade atmosfären signalerar å ena sidan ett tomrum som den kommunistiska inte har lyckats fylla och därmed dess illegitimitet. Tito är trots sin närvaro i själva verket frånvarande. Passagen fungerar därmed som ett omen om det kommunistiska 
projektets ohållbarhet. Å andra sidan är motsättningen mellan den leende Tito och de kvarlämnade döda insekterna ännu en metafor för regimens våld, där de försvarslösa insekterna symboliserar offren för det historiska vindslagets ödeläggande kraft på individen som regimens maktövertagande innebar. Ur det här perspektivet är Titos närvaro avgörande: det är han som är ansvarig för insekternas död. Man kan kanske ha i åtanke Julius berättelse från Arkhangelsk-lägret där man får veta att barnen som kom till lägret "died like flies» (Hemon, 2000, s. 9) som konsekvens av Stalins beslut att skicka dem dit. Lite tydligare är att insekterna är offer för pojkens fysiska auktoritet, då de bildligt talat återuppstår för att uttrycka sin ängslan över pojkens rörelse som innebär en ny våldsam överraskning. Detta har en allmängiltighet över sig som tycks innebära att auktoritetens våld är en universell princip som inte kan undgås.

Pojken träder in i en auktoritetsroll åtminstone ytterligare en gång i novellen, helt i slutet när familjen kommer tillbaka till sin lägenhet i Sarajevo efter semestern. Grannen som skulle ha passat familjens katt hade plötsligt dött och lämnat den utan mat. "The cat, not having been fed for more than a week, was emaciated and nearly mad with hunger. I would call her, but she wouldn't come to me, she would just look at me with irreversible hatred" (Hemon, 2000, s. 20). Katten blir ett offer för familjens auktoritet utan att detta på något sätt är intentionellt, vilket tycks betyda att auktoritet och makt nödvändigtvis för med sig offer. Samtidigt är bilden av fängsling och svält i Sarajevo ett omen om en kommande katastrof, kriget i Bosnien.

\section{Barnsoldaten}

Lazarevskas novell "Blagdan krunice» (Rosenkransfesten) från samlingen Biljke su nešto drugo (Växter är någonting annat) skiljer sig från Hemons "Islands» och i själva verket från de flesta texter som utnyttjar den kritiska barnfiguren, eftersom ett reellt barnperspektiv i den klassiska bemärkelsen saknas. Berättaren är en vuxen kvinna och hennes historia handlar om en grupp bošnjakiska kvinnor och barn som flyr undan bosnienserbiska soldater och etnisk rensning i ett ruralt område i Bosnien under kriget. Novellen tematiserar kvinnors erfarenhet av förföljelse och bearbetningen av trauma i ett mångbottnat intertextuellt fält och har flera meningslager, vars komplexitet inte kan presenteras till fullo här (se Avdagić, 2006; Postema, 2017). Jag har valt att uteslutande fokusera på ett smalt men viktigt utsnitt i novellen som har med barnfigurens funktion att göra.

Trots att barnfiguren, en pojke, inte är en central gestalt och blott spelar en roll glimtvis, lyckas bruket av den öppna upp för flera komplexa diskursiva frågor. I avsaknaden av ett barnperspektiv som präglas av ett barnsligt språk samt de typiska mentala och fysiska begränsningar som nämndes tidigare fungerar barnet i den här novellen främst som "reflektorfigur» (Spielmann, 2002, s. 225), eller en sorts spegling för de vuxna gestalterna - och inte minst den vuxna författaren. Detta kan till exempel innebära att en barnfigur ingår i en konversation med en vuxen och i det 
samtalet (med hjälp av sin speciella attityd till världen) katalyserar synvinklar som omkullkastar konventionella föreställningar. En stor del av Veličkovićs roman Otac moje kćeri (Min dotters far) från 2000 består av samtal mellan en vuxen berättare och en ung flicka, där flickan, utan att vara medveten om det, skapar eller sammanfattar kritiska synvinklar på det bosniska efterkrigssamhället. Andra gånger görs barnet till en projektionsyta som speglar samhälleliga frågor eller diskursiva processer. Irfan Horozovićs kortnovell "Igra» (Leken) från Prognani grad (Staden i exil, 1994) låter några barn på en skolgård mima de vuxnas hatiska etnicistiska diskurs som präglade upptakten till kriget. Genom att på sätt och vis "filtrera» diskursen genom de oskyldiga barnen förstärks eller förfrämligas intrycket av det fruktansvärda. Nedan vill jag koncentrera mig på barnet som projektionsyta för vad som kallats "one of the ideologically strongest figures symbolizing Yugoslav socialism», nämligen den jugoslaviska soldaten (Petrović, 2012, s. 85).

På ett sätt som påminner om pojken i "Islands» befinner sig den namnlösa pojken hos Lazarevska - han blir kallad "systersonen» - på en tröskel. Medan det hos Hemon handlar om en övergång i en mognads- och desillusioneringsprocess, så handlar det här om en övergång mellan två dominerande diskurser: den titoistiska och den etnonationalistiska. Lazarevska skildrar inte i första hand ett entydigt brott, där det ena paradigmet avslutas och det andra påbörjas. Snarare rör det sig om ett kontinuum, ett kontinuum av jugoslavisk militaristisk diskurs på systersonens kropp. Det är särskilt en central episod som aktualiserar de diskursiva mekanismerna:

\begin{abstract}
Det var så systersonen fick ett gevär i händerna i Travnik och blev en bosnisk soldat. Han var ännu för ung att vara en soldat, även om en hårlock ovanför hans högra tinning hade blivit grå över natten i Sokoline. Den bosniska armén hade alltjämt inte egen uniform, så när systersonen lade ned geväret såg han igen ut som en pojke. Det är så han framstår på fotografiet som publicerades i Travnički ljiljan 1992. Han är vänd mot kameran i halvprofil. Bildtexten under fotografiet lyder: en paus innan kamp. I Der Spiegel i oktober samma år lyder bildtexten, i översättning: två soldater i den bosniska armén och en bosnisk pojke. Der Spiegel har inte med fotografiet på omslaget av Travnički ljiljan, som föreställer en grupp av i allt arton soldater. Mot bakgrund av den klara himlen ser man topparna på tjugoen granar. Bildtexten lyder: den bosniska armén, starkare för var dag. (Lazarevska, 2003, s. 103; min övers.)
\end{abstract}

Lazarevska utnyttjar spänningen som finns mellan barnfiguren och soldatfiguren genom att aktivera två starkt antitetiska förväntningar som läsaren har på de två kategorierna. Det är inte som hos Hemon en fråga om det kritiska barnperspektivet utan snarare om en samling barnassociationer (oskuld, lek, hjälplöshet, barndom) som aktualiseras genom att blandas samman med soldatens (vapen, ödeläggelse, död, maskulinitet). Sammanblandningen sker genom hela passagen, där pojken tillåts gå in och ut ur rollen som soldat: han får först ett gevär och blir soldat, sedan lägger han ifrån sig vapnet och blir igen till pojke. Flimrandet mellan kategorierna fortsätter i fotografiet i Travnički ljiljan (pojken benämns som soldat) och i Der Spiegel (pojken är bara en pojke). Man kan tala om ett slags dubbelexponering, där två bilder läggs 
över varandra och skapar en tredje emergent och destabiliserande bild. Passagen är till dels fängslande därför att den spelar på ett moraliskt tabu att inte låta barn vara barnsoldater, men också för att den på ett diskursivt plan börjar lösa upp våra begrepp om "pojke» och "soldat». I dubbelexponeringen - i den tredje bilden - är det inte längre så tydligt var gränserna går mellan begreppen, vilket möjliggör en omförhandling och därmed ett avslöjande av de diskursiva mekanismer som står på spel i texten.

Tidigare var jag inne på hur Hemons "Islands» enligt Tygstrups och Holms terminologi skapade nya infallsvinklar genom att låta aspekter som exkluderats ur en dominerande titoistisk modernitetsdiskurs inkluderas i den för att på så vis träda fram och bli synliga. I "Rosenkransfesten» sker interventionen i den dominerande diskursen på ett annat sätt och som man kan tala om som exponering (exposition) (Tygstrup \& Holm, 2012, s. 209). Med exponering menas att en text används för att avslöja kritiserbara aspekter av en diskurs genom att låta denna diskurs vecklas ut, till synes på dess egna premisser, men i själva verket med en kritisk udd. Konsekvensen av denna sorts exponering är, för att använda Michail Bachtins ord (1984, s. 189), en stratifiering av den angripna diskursen, vilket gör att flera "intentioner» eller "röster» framträder och kommer i konflikt och förhandling om attityder, begrepp etc. Det är precis det som händer i Lazarevskas novell, även om jag hellre ser det som en korsning av olika diskurser som i själva verket inte är så tydligt avgränsade.

En bra ingång in i denna korsning är bilden av soldaten och särskilt frågan om uniformens betydelse. Lazarevskas förtydligande att pojken förvandlas till en bosnisk soldat är inte oviktigt och har direkt att göra med den bosniska arméns avsaknad av en standardiserad uniform. Avsaknaden innebär inte bara en osäkerhet om soldatens auktoritet utan också om själva hans identitet som soldat, vilket poängteras av att det enda som skiljer en soldat från en pojke är ett vapen - inte mer än det. I den jugoslaviska kontexten var soldatidentiteten ett komplext begrepp, en nod som samlade en rad sociala domäner och som definitivt betydde mer än att ha ett vapen $i$ händerna. För det första förknippades soldatrollen med utvecklingen av maskulinitet och karaktär som skulle präglas av den heroiska unga mannens vitalitet, moral och självuppoffring. I förlängningen var soldaten även en symbol för familjens deltagande $i$ det jugoslaviska projektet. Den jugoslaviska arméns (JNA) uniform skildras i novellen som en central och ärofull del av familjen när det påpekas att fotografiet av den äldsta sonen i uniform utgör en central del av hemmet: »När någon besökte ens hem var det brukligt att gästen först av allt tog en titt på fotot och konstaterade hur bra uniformen passade den unga mannen» (Lazarevska, 2003, s. 102; min övers.). Vidare "avslöjade det att hushållet hade försett den jugoslaviska nationella armén med en soldat» (Lazarevska, 2003, s. 102; min övers.), och detta var en stor ära. Pojkens inlemmande i den här diskursen indikeras bland annat av hans kunskap om uniformer, vapen och annan utrustning hos JNA. Det är han som tack vare denna förtrogenhet med jugoslavisk militär diskurs kan se en grupp soldater närma sig från långt håll och med säkerhet veta att de är bosnienserbiska soldater med JNA-utrustning. 
Det kan antas att förtrogenheten exempelvis kommer från medlemskap i Savez pionira fugoslavije (De jugoslaviska pionjärernas union), som var en organisation som stiftats av kommunisterna under andra världskriget och som mobiliserade barn och ungdomar att hjälpa Titos partisaner med såväl civila som militära uppgifter. Det kunde till exempel innebära något så farligt som att stjäla vapen från nazisterna, hålla utkik eller agera kurir (Erdei, 2004, s. 159). Även om den jugoslaviska staten i fredstid i högre grad prioriterade att pionjärerna skulle verka för ungdomens uppfostran och ingjuta känslor av "patriotism, Socialist spirit, and solidarity" (Bringa, 2004, s. 157), så präglades organisationen fortsatt av en starkt militaristisk diskurs. Pionjärernas egen uniform i blåvitröda färger, som bars på nationaldagen den 29 november, ansågs liksom JNA-uniformen som ett privilegium och en symbol för barnets (och familjens) bidrag till staten (Erdei, 2004, s. 155).

Avsaknaden av uniform hos Lazarevska innebär å ena sidan ett brott med en lång och komplex tradition, vars betydelsefulla sociala mervärde (om man kan kalla det så) förfaller i kriget. Den heroiska soldaten, exemplet på dygd och nationell stolthet, har nu blivit vem som helst med en bössa i handen. Det är en förråelse som rymmer en reell förlust. Ur det perspektivet framstår bildtexten i Travnički ljiljan, som trots hans ringa ålder identifierar pojken som soldat, som en etnonationalistisk korruption av en värdefull jugoslavisk tradition. Denna "bastardversion" av den heroiska soldaten kan ses som grunden för det Rosić (2012, s. 52) kallar för den »balkanska maskulinitetsmodellen» efter kriget, som präglats av en rad problematiska aspekter, såsom en chauvinistisk och nationalistisk krigskultur, glorifiering av kriminalitet och krigsprofitörer samt maskuliniseringen av den politiska sfären.

Å andra sidan - och jag tror att detta är den viktigare läsningen - framstår tidskriftens syn på pojken som soldat som ett prov på en kontinuitet i att uppfatta barn och ungdomar som pionjärer och potentiella soldater. I det ljuset är identifikationen mellan pojken och soldaten i själva verket mindre en bastardisk korruption än en gammal jugoslavisk vana. Det är på sätt och vis inte långt mellan att låta ungdomar stjäla vapen från nazistiska soldater under andra världskriget, som man säger att pionjärerna gjorde, till att låta dem ta upp vapen och strida i Bosnienkriget femtio år senare. Vad Lazarevska i första hand exponerar är naturligheten genom vilken pojken inkluderas i soldatkategorin i den jugoslaviska/postjugoslaviska militaristiska diskursen. De förutfattade egenskaperna som man kan förutsätta att läsaren attribuerar pojken - framför allt oskuldsfullheten som borde vara fri från ansvaret att ta andra människors liv - uppfattas överhuvudtaget inte alls inom den diskurs som representeras av Travnički ljiljan. Oskulden och pojkens barnstatus är inte ett hinder för att låta honom strida och diskursen tycks blind för distinktionen mellan barnet och soldaten. Att detta är ett jugoslaviskt/postjugoslaviskt problem understryks av publiceringen i tyska Der Spiegel, som publicerar samma bild som Travnički liiljan, men väljer en annan bildtext. Här är det tal om två bosniska soldater och en pojke - det finns ingen tvetydighet mellan begreppen. 


\section{Avslutning}

I motsättning till vad jag skulle vilja kalla den typiska användningen av det kritiska barnperspektivet, där barnet i hög grad äger agens och mer eller mindre medvetet och på egen hand formulerar kritik, gestaltar både Hemons "Islands» och Lazarevskas "Rosenskransfesten» barnen inte som ironiska hjältar, utan som offer för deras omgivning och de diskurser som präglar föreställningsvärlden i texterna. Hos Hemon antyds visserligen en väg ut, en emancipation från den titoistiska ideologin, men klaustrofobin är trots allt påtaglig, eftersom våldet och skräcken inte tycks sluta med kommunismen. Hos Lazarevska är fängslingen i diskursen ännu klarare. Det påpekas att systersonen till och med i efterkrigets exil i Prag har soldatambitionen inom sig när han möter en soldat på vakt och tävlar med honom om vem som kan stå stilla längst (Lazarevska, 2003, s. 123). Det kan läsas som en varning om den militaristiska diskursens rotfäste, som resonerar inte minst i efterkrigens intima förbindelse mellan maskulinitet och militarism.

Skildringen av "fängslingen" i dominerande strukturer är viktig och värd att understryka eftersom den i sig innebär en politisk handling i den mening som jag har stöttat mig på $i$ den här artikeln. I båda novellerna blir vi som läsare varse den avmakt, röstlöshet och brist på agens som individen har mitt i ett historiskt och omvälvande skeende där makthavare har stakat ut vägen. Vikten vid barnets röstlöshet, inte bara som en abstrakt idé utan som en erfarenhet, gör de diskursiva förhållandena som genomströmmar texterna mer trovärdiga och komplexa. Man kan se - i synnerhet hos Lazarevska - att det är svårt att tala om avgränsade dominerande diskurser, eftersom det är oklart vilka mekanismer som ska tillskrivas vilken diskurs. Har bilden av "barnsoldaten» rot i en jugoslavisk eller postjugoslavisk ideologisk diskurs? Bland annat på grund av denna oklarhet är "Rosenkransfesten» ett utmärkt exempel på att barnfiguren kan användas till mer än att förkasta ideologiska diskurser - den kan också vara ett analytiskt instrument för att uppenbara (exponera) deras beståndsdelar. Det intressanta med det kritiska barnperspektivet ligger med andra ord inte $i$ att barnen negerar de vuxnas ideologier ( $i$ de här novellerna sker heller inte det), utan $i$ att de sätter igång de angripna diskurserna vecklar ut eller animerar dem - på ett förfrämligande sätt som i slutändan avslöjar det förtryck de innebär på deras egna premisser.

\section{Referenser}

Avdagić, A. (2006). Politike reprezentacije: O nekoliko bosanskohercegovačkih pripovjedaka/priča s kraja 20. i početka 21. stoljeća, skica za dalja čitanja. Sarajevske sveske, 14, 321-336.

Avdagić, A. (2012). Narrative images of theYugoslav totality (and totalitarianism) in the Bosnian-Herzegovinian short story in the transition from the 20 th to the 21 st century. IT. Zimmermann (Red.), Balkan memories: media constructions of national and transnational history (s. 139-145). Bielefeld: Transcript Verlag.

Bakhtin, M. (1984). Problems of Dostoevsky's poetics (C. Emerson, Övers. \& Red.). Minneapolis: University of Minnesota Press. 


\section{$310 \mid$ FEDJA WIERØD BORČAK}

Beganović, D. (2012). Reflective and restorative nostalgia: Two types of approaching catastrophe in contemporary Yugoslav literature. I T. Zimmerman (Red.), Balkan memories: Media constructions of national and transnational history (s. 147-154). Bielefeld: Transcript Verlag.

Borčak, F. W. (2016). A children's literature? Subversive infantilisation in contemporary Bosnian-Herzegovinian fiction. Växjö: Linnaeus University Press.

Bringa, T. (2004). The peaceful death of Tito and the violent end of Yugoslavia. I J. Borneman (Red.), Death of the father: An anthropology of the end of political authority (s. 148-200). New York: Berghahn.

Denić-Grabić, A. (2010). Bosanskohercegovački roman na kraju 20. stoljeća: Konstrukcije narativnih identiteta: Kraj stoljeća $i$ bosanskohercegovački roman. Brčko: BZK Preporod.

Duda, I. (2010). Adriatic for all: Summer holidays in Croatia. I B. Luthar \& M. Pušnik (Red.), Remembering utopia: The culture of everyday life in socialist Yugoslavia (s. 289-311). Washington, DC: New Academia Publishing.

Edwards, J. \& Graulund, R. (2013). Grotesque. London: Routledge.

Erdei, I. (2004). "The happy child" as an icon of socialist transformation:Yugoslavia's pioneer organization. I J. Lampe \& M. Mazower (Red.), Ideologies and national identities: The case of twentieth-century southeastern Europe (s. 154-179). Budapest: Central European University Press.

Gavin, A. E. (2012). The child in British literature: An introduction. I A. E. Gavin (Red.), The child in British literature: Literary constructions of childhood, medieval to contemporary (s. 1-18). Basingstoke: Palgrave Macmillan.

Goodenough, E., Heberle, M. A. \& Sokoloff, N. B. (1994). Introduction. I E. Goodenough, M. A. Heberle \& N. B. Sokoloff (Red.), Infant tongues: The voice of the child in literature (s. 1-15). Detroit: Wayne State University Press.

Gorup, R. (2007). Representations of trauma in narratives of Goli Otok. Serbian Studies: Fournal of the North American Society for Serbian Studies, 21 (2), 151-160.

Hansen-Kokoruš, R. (2013). Formen adoleszenter Infantilität und ihre Funktionen. I R. Hansen-Kokoruš \& E. Popovska (Red.), Kind und Fugendlicher in der Literatur und im Film Bosniens, Kroatiens und Serbiens (s. 17-36). Hamburg: Verlag Dr. Kovač.

Hemon, A. (2000). Islands. I The question of Bruno (s. 1-20). London: Picador.

Kazaz, E. (2004). Prizori uhodanog užasa. Sarajesvke sveske, 5, 137-165.

Kovačević, M. (2012). Sarajevo. Paris: Actes Sud Editions.

Laclau, E. \& Mouffe, C. (2001). Hegemony and socialist strategy: Towards a radical democratic politics (2:a utg.). London: Verso.

Lazarevska, A. (2003). Blagdan krunice. I Biljke su nešto drugo (s. 101-124). Sarajevo: Buybook.

Nykvist, K. (2013). Through the eyes of a child: Childhood and mass dictatorship in modern European literature. I M. Schoenhals \& K. Sarsenov (Red.), Imagining mass dictatorships: The individual and the masses in literature and cinema (s. 94-120). Basingstoke: Palgrave Macmillan.

Petrović, T. (2012). Contested normality: Negotiating masculinity in narratives of service in the Yugoslav people's army. I D. Koleva (Red.), Negotiating normality: Everyday lives in socialist institutions (s. 83-102). New Brunswick, NJ: Transaction.

Postema, A. (2017). Claimed experience: Figuring trauma, narrating memory in wartime and postwar Bosnian fiction and film. (Ph.D.). Chicago: University of Chicago.

Rancière, J. (2009). Aesthetics and its discontents (S. Corcoran, Övers.). Cambridge: Polity Press.

Rancière, J. (2010). Ten theses on politics (S. Corcoran, Övers.). I S. Corcoran (Red.), Dissensus: On politics and aesthetics (s. 27-44). London: Continuum.

Rieff, D. (1994). Youth and consequences. The New Republic, 210(13), 31-34.

Rosić, T. (2012). Panika u redovima, tj. Balkan, zemlja s one strane ogledala. Sarajevske sveske, 39-40, 49-71.

Sheehan, D. (2018). In Sarajevo, a monument to childhood disrupted by war. Literary Hub. Hämtad den 19 juni 2018 från https://lithub.com/in-sarajevo-a-monument-to-childhood-disrupted-by-war/.

Spielmann, M. (2002). Aus den Augen des Kindes: Die Kinderperspektive in deutschsprachigen Romanen seit 1945. Innsbruck: Universität Innsbruck Inst. f. Germanistik.

Tygstrup, F. \& Holm, I. W. (2012). Cultural poetics and the politics of literature. I A. S. Hoel \& I. Folkvord (Red.), Ernst Cassirer on form and technology: Contemporary readings (s. 199-213). Basingstoke: Palgrave Macmillan.

Veličković, N. (2013). Der altkluge Erzähler. I R. Hansen-Kokoruš \& E. Popovska (Red.), Kind und fugendlicher in der Literatur und im Film Bosniens, Kroatiens und Serbiens (s. 225-243). Hamburg: Verlag Dr. Kovač. 
Vervaet, S. (2011). Writing war, writing memory: The representation of the recent past and the construction of cultural memory in contemporary Bosnian prose. Neohelicon, 38(1), 1-17.

Vice, S. (2005). Children's voices and viewpoints in holocaust literature. Holocaust Studies, 11(2), 11-24.

Zink, A. (2014). Land in Bewegung: Die Imagination Jugoslawiens in der bosnisch-kroatisch-serbischen Literatur. I T. Grob, B. Previšić \& A. Zink (Red.), Erzählte Mobilität im östlichen Europa: (Post-)Imperiale Räume zwischen Erfahrung und Imagination (s. 79-99). Tübingen: Zenodo. 